\title{
Isolation of Mitochondria From Fresh Mice Lung Tissue
}

\author{
Dayene de Assis Fernandes Caldeira ${ }^{1 t}$, Dahienne Ferreira de Oliveira ${ }^{2 t}$, \\ João Paulo Cavalcanti-de-Albuquerque', Jose Hamilton Matheus Nascimento', \\ Walter Araujo Zin ${ }^{1}$ and Leonardo Maciel ${ }^{1,3 *}$
}

${ }^{1}$ Carlos Chagas Filho Institute of Biophysics, Federal University of Rio de Janeiro, Rio de Janeiro, Brazil, ${ }^{2}$ Institute of Medical Biochemistry, Federal University of Rio de Janeiro, Rio de Janeiro, Brazil, ${ }^{3}$ Professor Geraldo Cidade Campus, Federal University of Rio de Janeiro, Duque de Caxias, Brazil

Direct analysis of isolated mitochondria enables a better understanding of lung dysfunction. Despite well-defined mitochondrial isolation protocols applicable to other tissues, such as the brain, kidney, heart, and liver, a robust and reproductive protocol has not yet been advanced for the lung. We describe a protocol for the isolation of mitochondria from lung tissue aiming for functional analyses of mitochondrial $\mathrm{O}_{2}$ consumption, transmembrane potential, reactive oxygen species (ROS) formation, ATP production, and swelling. We compared our protocol to that used for heart mitochondrial function that is well-established in the literature, and achieved similar results.

Keywords: lung mitochondria isolation, $\mathrm{O}_{2}$-consumption, ROS, ATP, mitochondrial assessment

\section{INTRODUCTION}

The assessment of mitochondrial function in organs and tissues is essential for a better understanding of their biochemistry, physiology, and pathophysiology (Weissig, 2005; Picard et al., 2011; Meyer et al., 2017; Murphy and Hartley, 2018). The evaluation of mitochondrial function is usually accomplished in isolated mitochondria (Picard et al., 2011; Gedik et al., 2017; Maciel et al., 2020, 2021; Caldeira et al., 2021) permeabilized fibers (Perry et al., 2013) or cells (Perry et al., 2013). These techniques are very well-defined in several types of tissue, e.g., heart (Gedik et al., 2017), kidney (Schulz et al., 2015), liver (Goudarzi et al., 2018), adipose tissue (Matta et al., 2021), and brain (Marques Neto et al., 2020), presenting peculiarities and different indications depending on the tissue and the purpose of the investigation. However, assessment of lung mitochondrial function presents difficulties associated with obtaining isolated, intact, coupled, and functional mitochondria. The methodological difficulty of obtaining viable lung mitochondria derives mainly from an elevated fatty acid content, low amount of mitochondria in the cell, fibrous and air-filled tissue, and the required amount of tissue (Spear and Lumeng, 1978; Kuznetsov et al., 2008; Lanza and Sreekumaran Nair, 2009). Recently, we have shown that the isolation of pulmonary mitochondria with preserved structure and function is possible by means of adaptations of existing techniques and standardization of a specific method of isolation by differentiated centrifugation (Caldeira et al., 2021). However, the differences related to mitochondrial isolation procedures for obtaining these well-preserved pulmonary mitochondria have not been addressed in detail, and the characteristics of reagents and equipment have not been fully described (Caldeira et al., 2021). Therefore, the main objective of this article is to provide a practical step-by-step user protocol upgraded to isolate pulmonary mitochondria. Our isolation protocol is founded on the differentiated centrifugation method of mice lung homogenate. However, unlike the classical procedures currently in use, we will use some innovative steps because of the intrinsic characteristics of the tissue to obtain better and more functional isolated mitochondria. In addition, we describe in detail the mitochondrial function pertaining to several respiratory complexes. 


\section{MATERIALS AND EQUIPMENT}

\section{Materials and Reagents}

1. Teflon beaker (BRAND ${ }^{\circledR}$ beaker, PTFE, low form, catalog number: Z322660; Merck, Darmstadt, Germany).

2. $50 \mathrm{ml}$ Falcon tubes (FALCON ${ }^{\circledR}$ Brand, $50 \mathrm{ml}$ polypropylene conical tube $30 \mathrm{~mm} \times 115 \mathrm{~mm}$ style, catalog number: 352070; Coring Science Mexico, Col del, Mexico).

3. $14 \mathrm{ml}$ round-bottom tubes (Thermo Scientific ${ }^{\mathrm{TM}}$, Nunc ${ }^{\mathrm{TM}}$ $14 \mathrm{ml}$ round-bottom tube, catalog number: 150268; Thermo Fisher Scientific ${ }^{\mathrm{TM}}$, Waltham, MA, United States).

4. 1.5 and $2 \mathrm{ml}$ microfuge tubes (Eppendorf Safe-Lock Tubes, 1.5 and $2 \mathrm{ml}$ Eppendorf Quality ${ }^{\mathrm{TM}}$, catalog numbers: 0030120086 and 0030120094, respectively; Eppendorf, Hamburgo, Germany).

5. Syringe filter (Corning ${ }^{\circledR}$ syringe filters, nylon membrane, diameter $25 \mathrm{~mm}$, pore size $0.2 \mu \mathrm{m}$, catalog number: CLS431224; Merck, Darmstadt, Germany).

6. Adjustable volumetric pipettes: 10 and $100 \mu \mathrm{l}$; and $5 \mathrm{ml}$ (PIPETMAN L P10L, 1-10 $\mu \mathrm{l}$; PIPETMAN L P100L, 10-100 $\mu$ l; PIPETMAN L P1000L, 100-1,000 $\mu$ l; PIPETMAN L P5000L, 500-5,000 $\mu \mathrm{l}$, metal ejector, catalog numbers: FA10002M, FA10004M, FA10006M, and FA10007, respectively; Gilson, Middleton, WI, United States).

7. Dispenser pipette $\left(\right.$ BRAND $^{\circledR}$ pipette withdraw volume $3.5 \mathrm{ml}$, catalog number: 747755; Merck, Darmstadt, Germany).

8. Hamilton syringe: 10 and $25 \mu \mathrm{l}$ (Hamilton ${ }^{\circledR}$ TLC syringes. catalog number: Z264385 and Z264393, respectively; Merck, Darmstadt, Germany).

9. Potter-Elvehjem PTFE pestle and glass tube (catalog number: P7859; Sigma-Aldrich, San Luis, MO, United States).

10. Silica glass cuvettes (Starna Scientific Ltd., Ilford, United Kingdom).

11. 96-well white plate, polystyrene, High Bind, white flatbottom wells, non-sterile, white (catalog number: CLS3922; Sigma-Aldrich, San Luis, MO, United States, Corning ${ }^{\circledR}$.

12. 96-well black plate, polystyrene, flat bottom, black polystyrene, matrix active group High Bind, non-sterile (catalog number: CLS3925; Sigma-Aldrich, San Luis, MO, United States, Corning ${ }^{\circledR}$ ).

13. 4-Morpholinepropanesulfonic (MOPS) acid (catalog number: M1254; CAS number: 1132-61-2; SigmaAldrich, San Luis, MO, United States); stored at room temperature (RT).

14. Adenosine $5^{\prime}$-diphosphate monopotassium salt dihydrate (ADP, catalog number: A5285, CAS number: 72696-481: Sigma-Aldrich, San Luis, MO, United States); stored at $-20^{\circ} \mathrm{C}$.

15. Adenosine $5^{\prime}$-triphosphate (ATP) assay mix (catalog number: FLAAM; Sigma-Aldrich, San Luis, MO, United States) stored at $-20^{\circ} \mathrm{C}$.

16. Amplex ${ }^{\mathrm{TM}}$ Red Reagent (catalog number: A12222; Thermo Fisher Scientific, Waltham, MA, United States) stored at $-20^{\circ} \mathrm{C}$.
17. Cyclosporin A (CsA, catalog number: 30024 , CAS number: 59865-13-3; Sigma-Aldrich, San Luis, MO, United States) stored at $-20^{\circ} \mathrm{C}$.

18. Ethylene-bis(oxyethylene dinitrilo)tetraacetic acid (EGTA, catalog number: E0396, CAS number: 6742-5; Sigma-Aldrich, San Luis, MO, United States) stored at RT.

19. Glutamic acid potassium (glutamate, catalog number: G1501, CAS number: 6382-01-0; Sigma-Aldrich, San Luis, MO, United States) stored at RT.

20. Bovine serum albumin (BSA, catalog number: A6003, CAS number: 9048-46-8; Sigma-Aldrich, San Luis, MO, United States) stored at $4^{\circ} \mathrm{C}$. Critical: BSA is used to remove (bind) free fatty acids; therefore, use BSA-free fatty acids.

21. Calcium chloride dihydrate $\left(\mathrm{CaCl}_{2}\right.$, catalog number: C3306, CAS number: 10035-04-8; Sigma-Aldrich, San Luis, MO, United States) stored at RT.

22. Carbonyl cyanide 4-(trifluoromethoxy)phenylhydrazone (FCCP, catalog number: C2920, CAS number: 370-86-5; Sigma-Aldrich, San Luis, MO, United States) stored at $4^{\circ} \mathrm{C}$.

23. L-Ascorbic acid (ascorbate, catalog number: A5960, CAS number: 50-81-7; Sigma-Aldrich, San Luis, MO, United States) stored at $4^{\circ} \mathrm{C}$.

24. Magnesium chloride hexahydrate $\left(\mathrm{MgCl}_{2}\right.$, catalog number: M2393, CAS number: 7791-18-6; Sigma-Aldrich, San Luis, MO, United States) stored at $4^{\circ} \mathrm{C}$.

25. L-(-)-Malic acid (malate, catalog number: M1000; CAS number: 97-67-6; Sigma-Aldrich, San Luis, MO, United States) stored at RT.

26. N-(2-Hydroxyethyl)piperazin- $\mathrm{N}^{\prime}$-(2-ethanesulfonic acid)] (HEPES, catalog number: H7006; CAS number: 75277-39-3; Sigma-Aldrich, San Luis, MO, United States) stored at RT.

27. N,N,N,N-Tetramethyl-p-phenylenediamine dihydrochloride (TMPD, catalog number: T739; Sigma-Aldrich, San Luis, MO, United States) stored at RT.

28. Potassium chloride (KCl, catalog number: P5405, CAS number: 7447-40-7; Sigma-Aldrich, San Luis, MO, United States) stored at RT.

29. Potassium dihydrogen phosphate $\left(\mathrm{KH}_{2} \mathrm{PO}_{4}\right.$, catalog number: P5655, CAS number: 7778-77-0; Sigma-Aldrich, San Luis, MO, United States) stored at RT.

30. Sodium phosphate dibasic $\left(\mathrm{Na}_{2} \mathrm{HPO}_{4}\right.$, catalog number: S3264, CAS number: 7558-79-4; Sigma-Aldrich, San Luis, MO, United States) stored at RT.

31. Succinic acid (succinate, catalog number: S3674, CAS number: 110-15-6; Sigma-Aldrich, San Luis, MO, United States) stored at RT.

32. Sucrose (catalog number: S7903, CAS number: 57-50-1; Sigma-Aldrich, San Luis, MO, United States) stored at RT.

33. Trizma base (Tris, catalog number: T6066, CAS number: 77-86-1; Sigma-Aldrich, San Luis, MO, United States) stored at RT.

34. Tetramethylrhodamine methyl ester perchlorate (TMRM, catalog number: T5428, CAS number: 115532-50-8; Sigma-Aldrich, San Luis, MO, United States) stored at $-20^{\circ} \mathrm{C}$. 


\section{Recipes}

1. Isolation buffer in mmol/l: sucrose 250; HEPES 10; EGTA 1, $\mathrm{pH}$ 7.4. Dissolve $85.58 \mathrm{~g}$ of sucrose, $2.6 \mathrm{~g}$ of HEPES, and $0.38 \mathrm{~g}$ of EGTA in $800 \mathrm{ml}$ of ultrapure water. Adjust $\mathrm{pH}$ to 7.4 using $2 \mathrm{~mol} / \mathrm{l}$ Tris, and bring the solution to $1 \mathrm{~L}$ and store at $4^{\circ} \mathrm{C}$.

2. BSA isolation buffer: Dissolve $400 \mathrm{mg}$ of BSA fat-free in $50 \mathrm{ml}$ isolation buffer.

3. Electrolyte solution in mmol/l: $\mathrm{Na}_{2} \mathrm{HPO}_{4} 374 ; \mathrm{KH}_{2} \mathrm{PO}_{4}$ 191; KCl 139.5; $\mathrm{NaN}_{3}$ 15.38. Dissolve $2.655 \mathrm{~g}$ of $\mathrm{Na}_{2} \mathrm{HPO}_{4}$, $1.3 \mathrm{~g}$ of $\mathrm{KH}_{2} \mathrm{PO}_{4}$, and $0.52 \mathrm{~g}$ of $\mathrm{KCl}$ in $50 \mathrm{ml}$ ultrapure water. Add $0.05 \mathrm{~g}$ of $\mathrm{NaN}_{3}$ and a few crystals of $\mathrm{AgCl}$ to provide a saturated solution. Filtrate the solution and store at $4^{\circ} \mathrm{C}$. Caution: $\mathrm{NaN}_{3}$ is highly toxic.

4. Incubation buffer for respiration pyruvate/malate (IBRP/M) in mmol/l: $125 \mathrm{KCl} ; 10 \mathrm{MOPS} ; 5 \mathrm{MgCl}_{2} ; 5$ $\mathrm{KH}_{2} \mathrm{PO}_{4} ; 0.02$ EGTA; 5 pyruvate/malate, $\mathrm{pH}$ 7.4. Add $6.25 \mathrm{ml}$ of $1 \mathrm{~mol} / 1 \mathrm{KCl}, 1 \mathrm{ml}$ of $500 \mathrm{mmol} / \mathrm{l} \mathrm{MOPS}$, $0.1 \mathrm{ml}$ of $1 \mathrm{~mol} / 1 \mathrm{MgCl}_{2}, 0.25 \mathrm{ml}$ of $1 \mathrm{~mol} / \mathrm{K} \mathrm{KH}_{2} \mathrm{PO}_{4}$, $0.1 \mathrm{ml}$ of $100 \mathrm{mmol} / \mathrm{l} \mathrm{EGTA}$, and $1 \mathrm{ml}$ of $250 / 250 \mathrm{~mol} / \mathrm{l}$ pyruvate/malate. Adjust $\mathrm{pH}$ to 7.4 using $500 \mathrm{mmol} / \mathrm{l} \mathrm{Tris,}$ and bring the solution to $50 \mathrm{ml}$ using ultrapure water and filtrate it. Store at $4^{\circ} \mathrm{C}$.

5. Incubation buffer for respiration succinate (IBRS) in mmol/l: $125 \mathrm{KCl} ; 10 \mathrm{MOPS} ; 5 \mathrm{MgCl}_{2} ; 5 \quad \mathrm{KH}_{2} \mathrm{PO}_{4} ; 0.02$ EGTA; 5 succinate, $\mathrm{pH} 7.4$. Add $6.25 \mathrm{ml}$ of $1 \mathrm{~mol} / \mathrm{l} \mathrm{KCl}, 1 \mathrm{ml}$ of $500 \mathrm{mmol} / \mathrm{l} \mathrm{MOPS}, 0.1 \mathrm{ml}$ of $1 \mathrm{~mol} / \mathrm{l} \mathrm{MgCl}, 0.25 \mathrm{ml}$ of $1 \mathrm{~mol} / \mathrm{l} \mathrm{KH} \mathrm{PO}_{4}, 0.1 \mathrm{ml}$ of $100 \mathrm{mmol} / \mathrm{l} \mathrm{EGTA}$, and $1 \mathrm{ml}$ of $250 \mathrm{mmol} / \mathrm{l}$ succinate. Adjust $\mathrm{pH}$ to 7.4 using $0.5 \mathrm{~mol} / \mathrm{l} \mathrm{Tris}$, and bring the solution to $50 \mathrm{ml}$ using ultrapure water, and filtrate it and store at $4^{\circ} \mathrm{C}$.

6. $100 \mathrm{mmol} / \mathrm{l} \mathrm{ADP}$ : Dissolve $427 \mathrm{mg}$ of ADP in $10 \mathrm{ml}$ of ultrapure water. Prepare $100 \mu \mathrm{l}$ aliquots and store at $-20^{\circ} \mathrm{C}$.

7. $500 \mathrm{mmol} / \mathrm{l}$ ascorbate: Dissolve $880.65 \mathrm{mg}$ of ascorbic acid in $10 \mathrm{ml}$ of ultrapure water. Prepare $100 \mu \mathrm{l}$ aliquots and store at $-20^{\circ} \mathrm{C}$.

8. $10 \mathrm{mmol} / \mathrm{l}$ calcium chloride: Dissolve $55.49 \mathrm{mg}$ of $\mathrm{CaCl}_{2}$ in $50 \mathrm{ml}$ of ultrapure water and store at $-20^{\circ} \mathrm{C}$.

9. $10 \mathrm{mmol} / \mathrm{l}$ cyclosporin A: Dissolve $12 \mathrm{mg}$ of cyclosporin A in $1 \mathrm{ml}$ of absolute ethanol and store at $-20^{\circ} \mathrm{C}$.

10. $0.1 \mathrm{~mol} / \mathrm{l}$ EGTA stock solution: Dissolve $1.9 \mathrm{~g}$ of EGTA in $30 \mathrm{ml}$ of ultrapure water. Adjust $\mathrm{pH}$ to 7.4 using $0.5 \mathrm{~mol} / \mathrm{l}$ Tris and dilute to $50 \mathrm{ml}$. Store at $4^{\circ} \mathrm{C}$.

11. $10 \mathrm{mmol} / \mathrm{l} \mathrm{FCCP} \mathrm{stock} \mathrm{solution:} \mathrm{Dissolve} 2.5 \mathrm{mg}$ of FCCP in $1 \mathrm{ml}$ of absolute ethanol. Store at $-20^{\circ} \mathrm{C}$. Dilute the stock solution to $5 \mu \mathrm{M}$ by adding $5 \mu \mathrm{l}$ of $10 \mathrm{mmol} / \mathrm{l} \mathrm{FCCP} \mathrm{in}$ $10 \mathrm{ml}$ of absolute ethanol. Prepare $20 \mu \mathrm{l}$ aliquots and store at $-20^{\circ} \mathrm{C}$.

12. $0.25 \mathrm{~mol} / \mathrm{l}$ Pyruvate $/ 0.25 \mathrm{~mol} / \mathrm{l}$ malate stock solution: Dissolve $1.38 \mathrm{~g}$ of pyruvate and $1.68 \mathrm{~g}$ of malate in $30 \mathrm{ml}$ of ultrapure water and adjust $\mathrm{pH}$ to 7.4 with $2 \mathrm{~mol} / \mathrm{l}$ Tris. Dilute to $50 \mathrm{ml}$ and store at $4^{\circ} \mathrm{C}$.

13. $1 \mathrm{~mol} / \mathrm{l} \mathrm{KCl} \mathrm{stock} \mathrm{solution:} \mathrm{Dissolve} 18.64 \mathrm{~g}$ of $\mathrm{KCl}$ in $250 \mathrm{ml}$ of ultrapure water and store at $4^{\circ} \mathrm{C}$.
14. $1 \mathrm{~mol} / 1 \mathrm{KH}_{2} \mathrm{PO}_{4}$ stock solution: Dissolve $6.8 \mathrm{~g}$ of $\mathrm{KH}_{2} \mathrm{PO}_{4}$ in $30 \mathrm{ml}$ of ultrapure water. Adjust $\mathrm{pH}$ to 7.4 using $0.5 \mathrm{~mol} / \mathrm{l}$ Tris and dilute to $50 \mathrm{ml}$. Store at $4^{\circ} \mathrm{C}$.

15. $1 \mathrm{~mol} / \mathrm{l} \mathrm{MgCl} 2$ stock solution: Dissolve $4.7 \mathrm{~g}$ of $\mathrm{MgCl}_{2}$ in $50 \mathrm{ml}$ of ultrapure water and store at $4^{\circ} \mathrm{C}$.

16. $0.5 \mathrm{~mol} / \mathrm{l}$ MOPS stock solution: Dissolve $10.46 \mathrm{~g}$ of MOPS in $30 \mathrm{ml}$ of ultrapure water. Adjust $\mathrm{pH}$ to 7.4 using $0.5 \mathrm{~mol} / \mathrm{l}$ Tris and dilute to $100 \mathrm{ml}$. Store at $4^{\circ} \mathrm{C}$.

17. $1 \mathrm{mmol} / \mathrm{l}$ rotenone stock solution: Dissolve $3.9 \mathrm{mg}$ of rotenone in $10 \mathrm{ml}$ of absolute ethanol. Dilute the stock solution to $500 \mu \mathrm{mol} / \mathrm{l}$ by adding $5 \mathrm{ml}$ of $1 \mathrm{mM}$ rotenone in $5 \mathrm{ml}$ of absolute ethanol. Prepare 200- $\mu \mathrm{l}$ aliquots and store at $-20^{\circ} \mathrm{C}$ (critical step). Rotenone is light-sensitive. The stock solution should be protected from direct light.

18. $0.25 \mathrm{~mol} / \mathrm{l}$ succinate stock solution: Dissolve $2.02 \mathrm{~g}$ of succinate in $30 \mathrm{ml}$ of ultrapure water and adjust $\mathrm{pH}$ to 7.4 with $2 \mathrm{~mol} / \mathrm{l}$ Tris. Dilute to $50 \mathrm{ml}$ and store at $4^{\circ} \mathrm{C}$.

19. $150 \mathrm{mmol} / \mathrm{l}$ TMPD: Dissolve $49.3 \mathrm{mg}$ of TMPD in $2 \mathrm{ml}$ DMSO. Prepare $10-\mu \mathrm{l}$ aliquots and store at $-20^{\circ} \mathrm{C}$.

20. $2 \mathrm{~mol} / \mathrm{l}$ Tris: Dissolve $121.14 \mathrm{~g}$ of Tris in $500 \mathrm{ml}$ of ultrapure water. Dilute to $0.5 \mathrm{~mol} / \mathrm{l}$ by adding $250 \mathrm{ml} 2 \mathrm{~mol} / \mathrm{l}$ Tris in $750 \mathrm{ml}$ ultrapure water and store at RT.

21. $5 \mathrm{mmol} / \mathrm{l}$ TMRM stock solution: Dissolve $5 \mathrm{mg}$ of TMRM in $2 \mathrm{ml}$ of DMSO. Store at $-20^{\circ} \mathrm{C}$.

\section{Equipment}

1. Surgery scissors (ABC instrumentos cirúrgicos, surgery scissors straight $12 \mathrm{~cm}$, code: 321. Catalog number: 10304850053).

2. Refrigerated highest-speed centrifuge (Mikro 200R; Hettich, Tuttlingen, Germany).

3. Tissue homogenizer (T 25 Digital ULTRA-TURRAX ${ }^{\circledR}$, catalog number: 3725000; Merck, Darmstadt, Germany).

4. Clark-type oxygen electrode and respirometer MT200A (oxygen meter, 782, MT200A; Strathkelvin, Motherwell, Scotland).

5. Spectrofluorimeter SpectraMax ${ }^{\circledR}$ M3 (SpectraMax ${ }^{\circledR}$ M3; Molecular Devices, San Jose, CA, Untied States).

6. Centrifuges and rotors: Precool centrifuges and rotors to $4^{\circ} \mathrm{C}$.

7. Oxygraph chamber: Adjust the temperature of the water bath to $37^{\circ} \mathrm{C}$. Calibrate the Clarke-type oxygen electrode. Procedures may vary from instrument to instrument. Follow the manual for the oxygen electrode and chamber you are using (Strathkelvin 782 2-channel Oxygen System version 1.0; Strathkelvin, Motherwell, Scotland).

8. Spectrophotometer: Adjust the temperature of the cuvette block to $37^{\circ} \mathrm{C}$.

\section{Software}

1. Strathkelvin 782 2-channel Oxygen System version 1.0 (Oxygenmeter, 782; Strathkelvin, Motherwell, Scotland).

2. SoftMax ${ }^{\circledR}$ Pro Software (Molecular Devices, San Jose, CA, United States).

3. GraphPad Prism 8.4.3 (San Diego, CA, United States). 


\section{METHODS}

\section{Animals}

CD-1 mice (25-30 g BW) were used. The animal study was reviewed and approved by our institutional ethics committee on the use of animals (Health Sciences Center, Federal University of Rio de Janeiro (protocol 015/17) and followed the guidelines of the Brazilian National Council for Animal Experimentation Control, Ministry of Science, Technology, and Innovation (CONCEA/MCTI), and the Guide for the Care and Use of Laboratory Animals published by the United States National Institutes of Health (8th edition, 2011).

\section{Isolation of Mitochondria}

The experimental protocol must be available after lung mitochondrial isolation, because mitochondria are viable for about 4 h only (critical step).

\section{Collection of Tissue Samples (Timing Is $2-5$ Min Per Animal)}

The mice were euthanized and underwent a bilateral thoracotomy. The lungs were carefully removed en bloc and immediately placed in a tube containing an ice isolation buffer at $4^{\circ} \mathrm{C}$ (see section "Recipes") to remove excess blood.

\section{Isolation of Mitochondria (Timing Is Approximately 40-90 Min)}

The following steps are critical for the isolation of mitochondria (critical step). Mistakes during mitochondria isolation are irreversible and can spoil the running experiment. All processes must be performed on ice. Centrifugation steps at $4^{\circ} \mathrm{C}$ and buffers should be precooled during processing. It is important to work fast to avoid delays in tissue preparation (Figure 1).

a. Remove the adipose tissue and all large vessels using scissors.

b. Mince the tissue into 1-2 $\mathrm{g}$ fragments and transfer each one into a Teflon beaker with $10 \mathrm{ml}$ BSA isolation buffer on ice.

c. Remove all remaining fat. The tissue must be thoroughly minced, since the size of the sample directly affects the subsequent homogenization step and eventually the yield of mitochondria (critical step). Ensure the removal of all fats that also affect the yield of mitochondria.

d. Split the minced tissue from one Teflon beaker into two 14$\mathrm{ml}$ round-bottom tubes. The tube should not contain more than $2 \mathrm{ml}$ tissue volume. Whenever necessary, use more 14$\mathrm{ml}$ round-bottom tubes.

e. Wash the minced tissue samples: fill the 14-ml roundbottom tubes with $10 \mathrm{ml} \mathrm{BSA}$ isolation buffer, let the tissue sink, remove the buffer, and repeat tissue washing until the buffer is clear (the minced tissue would then contain no blood). Usually, four or five washings are enough to obtain a clean BSA isolation buffer. Hence, fill the 14-ml roundbottom tubes up to $6 \mathrm{ml}$ with isolation buffer. The optimal tissue/buffer ratio is 1:3 or less. After mincing the tissue, part of it precipitates and some pieces float because of the air in the air spaces (critical step). Be careful in removing the blood during washing to avoid tissue loss.

f. Homogenize the samples with the tissue homogenizer (Ultra-Turrax) using two 10-s treatments at a shaft rotation rate of $6,500 \times \mathrm{g}$ each. Perform the homogenization on ice with slight movements of the centrifuge tube. Wait for $10 \mathrm{~s}$ between the homogenization steps to avoid heating of the homogenizer and the samples, and to avoid foaming (critical step).

g. Collect the samples and transfer them to a tissue glass Potter-Elvehjem homogenizer. Homogenize the samples, and stroke the suspension about 30-40 times. This procedure can compromise mitochondrial integrity if not done carefully (critical step). It Is recommended to precool the glassware in an ice bath 5-10 min before starting the procedure. Attention: The use of proteases, e.g., nargase, during mitochondrial isolation, commonly performed in other tissues such as the heart, ruins the whole process.

h. Centrifuge the homogenate at $700 \times \mathrm{g}$ for $10 \mathrm{~min}$ at $4^{\circ} \mathrm{C}$.

i. Collect the supernatant in 2-ml microfuge tubes and discard the pellets. Centrifuge the supernatant at $12,300 \times \mathrm{g}$ for $10 \mathrm{~min}$ at $4^{\circ} \mathrm{C}$.

j. Discard the supernatant and resuspend the pellet in $0.5 \mathrm{ml}$ of ice-cold isolation buffer by gentle pipetting, and collect the mitochondrial suspensions in 2-ml microfuge tubes. Avoid the formation of foam during the resuspension process (critical step).

$\mathrm{k}$. Centrifuge the supernatant in ice-cold isolation buffer at $10,300 \times \mathrm{g}$ for $10 \mathrm{~min}$ at $4^{\circ} \mathrm{C}$.

1. Pool all the mitochondrial suspensions in one 2-ml microfuge tube and repeat the previous step.

$\mathrm{m}$. Resuspend the resulting pellet in 100-200 $\mu \mathrm{l}$ isolation buffer and store it on ice. Resuspend the pellets carefully by gentle pipetting to obtain a uniform suspension without any visible clump (critical step).

n. Measure mitochondrial concentration using the Lowry or BSA method.

\section{Pause Point}

At this point, the mitochondria are ready to be used in experiments to explore their function. Use the preparation within $4 \mathrm{~h}$ for better functional responses. Store the mitochondrial suspension on ice.

Note: The isolated mitochondria by this protocol can be used in different oximeter equipment, and can be analyzed with different software and methodologies.

\section{Mitochondrial Oxygen Consumption (Timing: Approximately 10-20 Min Per Measurement)}

In each experiment, use $200 \mu \mathrm{g}$ of protein per $\mathrm{ml}$ for good acquisition data. The oxygen consumption gives information about the electron transport chain and the oxidative phosphorylation of the mitochondria. By the addition of substrates and inhibitors, or by uncoupling oxidative phosphorylation, it is possible to modulate the rate of oxygen 



FIGURE 1 | Mitochondrial isolation. First, (a,b) lungs were removed in bloc from euthanized mice. (c) Lung tissue was minced with scissors and (d) washed with BSA isolation buffer four to five times to eliminate blood. (e) The sample was homogenized with a high-speed tissue homogenizer and, again, with tissue glass Potter-Elvehjem homogenizer carefully, to achieve cell disruption without compromising mitochondrial integrity (f). (g) The homogenate was centrifuged at $700 \mathrm{~g}$ for 10 min at $4^{\circ} \mathrm{C}$. (h) The pellet was discarded, and the supernatant was collected and submitted to differential centrifugation. Finally, (i) the resultant pellet containing mitochondria was ready to be used in functional analyses.

consumption and gain further insight into the activity of each complex of the electron transport chain.

At this point, mitochondrial complexes I (states 1, 2, and 3 ), II (state 3 ), and IV respiration with subsequent uncoupling of oxidative phosphorylation were measured in a two-chamber respirometer. With two different chambers, it is possible to measure two different experimental groups at the same time, observing results in mitochondrial function in parallel (critical step). Moreover, the respiration of complex I and complex II can be available in parallel using two different chambers.

a. Add $0.5 \mathrm{ml}$ of IBRP/M buffer to the chambers. One can opt to add IBRP/M without pyruvate/malate (or $5 \mathrm{mmol} / \mathrm{l}$ glutamate $/ 5 \mathrm{mmol} / \mathrm{l}$ malate, bypassing the critical step of pyruvate decarboxylation, which is highly dependent on $\mathrm{NAD}^{+}$) to measure the state 1 respiration of complex I and to add IBRS plus $2 \mu \mathrm{mol} / \mathrm{l}$ rotenone to the other chamber to measure complex II respiration. Make sure that the magnetic stirrer moves constantly. Rotenone is sticky and inhibits complex I respiration (critical step). Therefore, we suggest washing each chamber that received rotenone with a cardiac or liver tissue homogenate to assist the removal of rotenone. Additionally, we recommend washing the chamber three times with $70^{\circ}$ alcohol, followed by three washes with EDTA $100 \mathrm{mmol} / \mathrm{l}$. Finally, wash 10 times with MilliQ water.

b. Equilibrate the temperature and oxygen tension of the buffer and close the chamber. Usually, 3-4 min are sufficient until the oxygen concentration in the chamber remains stable.

c. Start the recording of the oxygen concentration in the chamber. Steady-state recording without drifts is mandatory (critical step). Wait for 1-5 min to obtain a stable baseline. A maximal drift of $\pm 10 \mathrm{nmol} \mathrm{O}_{2} / \mathrm{min}$ is considered acceptable once endogenous substrates could be present in the preparation starting State 2 respiration before the addition of the exogenous substrate. Add $200 \mu \mathrm{g}$ of mitochondrial protein using a Hamilton syringe and record for $3 \mathrm{~min}$. If one chooses to add IBRP/M without pyruvate/malate, the state 1 of complex I is measured. One should add pyruvate/malate $5 \mu \mathrm{mol} / \mathrm{l}$, and the oxygen concentration in the chamber will decrease because of oxygen consumption by the mitochondria, which can be referred to as state 2 complex 1 respiration. and record for 3 min (Figure 2).

d. Add $4 \mu \mathrm{l}$ of $100 \mathrm{mmol} / \mathrm{l} \mathrm{ADP}$ to obtain a final concentration of $400 \mu \mathrm{mol} / \mathrm{l}$ using a Hamilton syringe and record oxygen concentration for $3 \mathrm{~min}$ (Figure 2). 


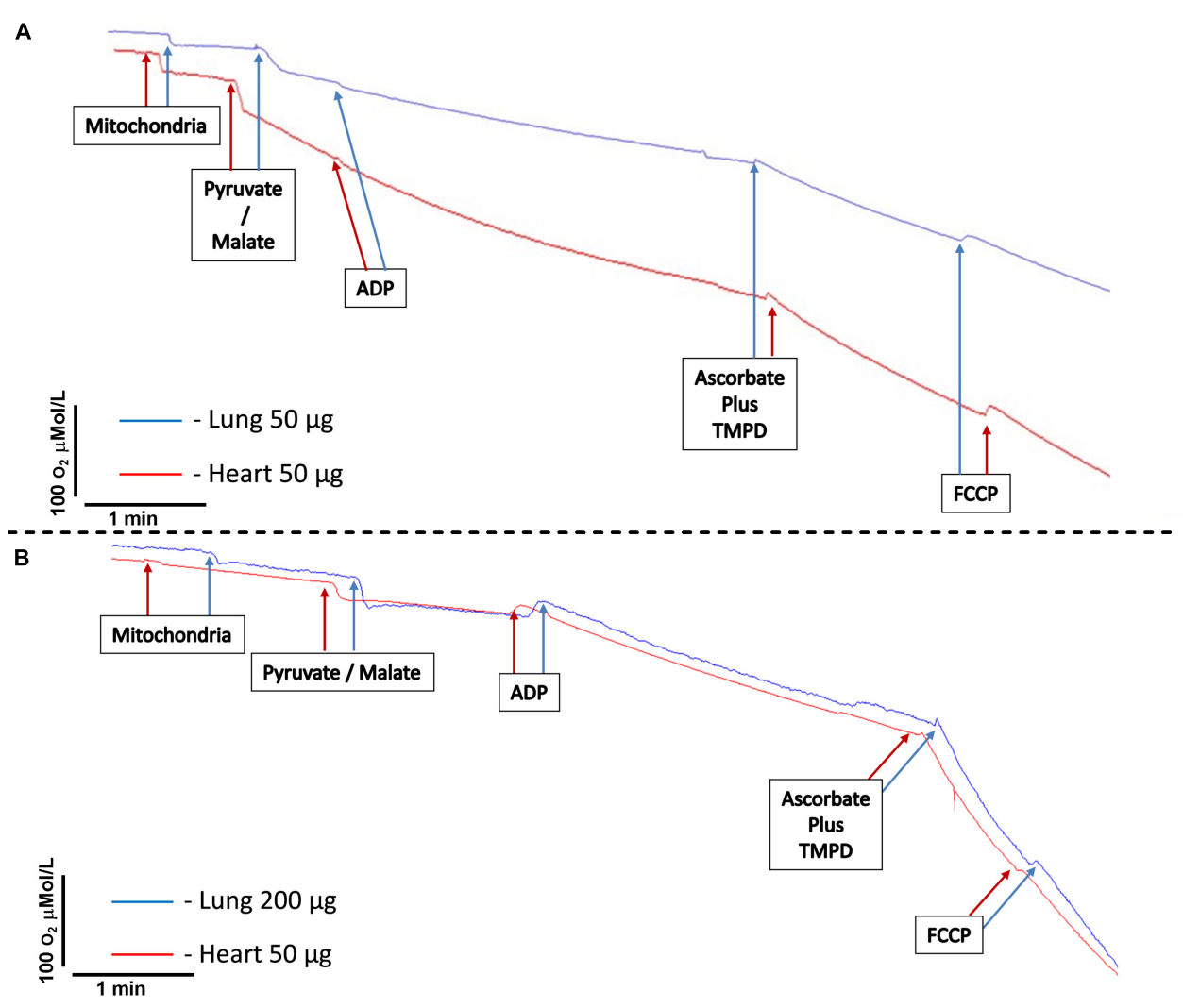

FIGURE 2 | Representative tracings of mitochondria oxygen consumption. (A) Comparison between isolated mitochondria loading from heart (50 $\mu \mathrm{g}$ ) and lung $(50 \mu \mathrm{g})$ tissues. (B) Comparison between isolated mitochondria loading from heart $(50 \mu \mathrm{g})$ and lung $(200 \mu \mathrm{g})$ tissues. Mitochondria represents the moment of the addition of isolated mitochondria. Pyruvate/malate represents the time of addition of pyruvate $5 \mu \mathrm{mol} / \mathrm{L} / \mathrm{malate} 5 \mu \mathrm{mol} / \mathrm{L}$. ADP signals the time to add ADP $400 \mu \mathrm{mol} / \mathrm{L}$. Ascorbate $3 \mathrm{mmol} / \mathrm{L}$ plus N,N,N,N-tetramethyl-p-phenylenediamine dihydrochloride (TMPD) $300 \mu \mathrm{mol} / \mathrm{L}$ indicates the addition of ascorbate and TMPD. FCCP indicates the addition of carbonyl cyanide 4-(trifluoromethoxy)phenylhydrazone $30 \mathrm{nmol} / \mathrm{L}$.

e. The decrease in oxygen concentration speeds up, caused by stimulating mitochondrial respiration with $\mathrm{ADP}$ (state 3). ADP-stimulated respiration should be faster than baseline respiration, reflecting good coupling of mitochondria (critical step). The respiration could slow down and return to a rate comparable to that of the baseline respiratory state, as result of the conversion of all added ADP and phosphate into ATP.

f. Add simultaneously $2 \mu \mathrm{l}$ of $150 \mathrm{mmol} / \mathrm{l}$ TMPD and $6 \mu \mathrm{l}$ of $500 \mathrm{mmol} / \mathrm{l}$ ascorbate to obtain final concentrations of 300 and $3 \mathrm{mmol} / \mathrm{l}$, respectively. Record oxygen concentration for $1 \mathrm{~min}$. The oxygen concentration will decrease faster than with ADP stimulation. TMPD is an electron donor to complex VI, which is readily reduced by ascorbate and oxidized by cytochrome $\mathrm{C}$ (Figure 2).

g. Add $6 \mu \mathrm{l}$ of $5 \mu \mathrm{mol} / \mathrm{l}$ FCCP to obtain a final concentration of $30 \mathrm{nmol} / \mathrm{l}$. Record oxygen concentration for $1 \mathrm{~min}$. The oxygen concentration will decrease further. FCCP is an uncoupling agent, which turns the mitochondrial membrane permeable to protons and, therefore, eliminates the chemiosmotic gradient. As a result, ATP synthesis is disrupted (Figure 2).

h. Stop recording.

i. Calculate mitochondrial oxygen consumption using the software Analysis (Strathkelvin 782 2-channel Oxygen System version 1.0; Strathkelvin, North Lanarkshire, Scotland) or similar. Calculate baseline oxygen consumption $75 \mathrm{~s}$ after the addition of mitochondria. Calculate state 2 complex I oxygen consumption $75 \mathrm{~s}$ after the addition of pyruvate/malate. Determine ADP-stimulated respiration $30 \mathrm{~s}$ after the addition of ADP. Determine complex VI respiration $30 \mathrm{~s}$ after the addition of ascorbate/TMPD. Calculate maximal uncoupled respiration rate $30 \mathrm{~s}$ after the addition of FCCP.

\section{Measurement of Adenosine 5'-Triphosphate Production (Timing: Approximately 20 Min)}

In the respiration chamber, repeat all the steps up to adding $4 \mu \mathrm{l}$ of $100 \mathrm{mmol} / \mathrm{l} \mathrm{ADP}$ to obtain a final concentration of $400 \mu \mathrm{mol} / \mathrm{l}$. Then, record the ADP-stimulated respiration 
for $3 \mathrm{~min}$. Thereafter, the incubation buffer containing mitochondria should be transferred to an Eppendorf tube and immediately supplemented with ATP assay mix (ATP Bioluminescence Assay Kit; Sigma-Aldrich, St. Louis, MO, United States) diluted to 1:5 (incubation buffer containing mitochondria: ATP assay mix). Mitochondrial ATP production was determined immediately after each respiration measurement and compared with ATP standards using a 96-well white plate in a spectrofluorometer (SpectraMax ${ }^{\circledR}$ M3; Molecular Devices, San Jose, CA, United States) at 560-nm emission.

\section{Measurement of Mitochondrial ROS (Timing: Approximately $\mathbf{3 0}$ Min)}

The Amplex Red Hydrogen Peroxide Assay (catalog number: A12222; Thermo Fisher Scientific, Waltham, MA, United States) was used to determine mitochondrial ROS concentration. Amplex Red reacts in 1:1 stoichiometry with peroxide in the presence of horseradish peroxidase (HRP) and produces highly fluorescent $95 \%$ resorufin. The incubation buffer containing mitochondria should be transferred to an Eppendorf tube and immediately supplemented with $50 \mu \mathrm{mol} / \mathrm{l}$ Amplex UltraRed Reagent (Thermo Fisher Scientific, Waltham, MA, United States) and $2 \mathrm{U} / \mathrm{ml}$ Pierce ${ }^{\mathrm{TM}}$ horseradish peroxidase (HRP, catalog number: 31491; Thermo Fisher Scientific, Waltham, MA, United States). The supernatant was collected after $20 \mathrm{~min}$ of incubation in the dark. Mitochondrial ROS concentration was determined and compared with $\mathrm{H}_{2} \mathrm{O}_{2}$ standards using a 96well black plate and a spectrofluorometer (SpectraMax ${ }^{\circledR}$ M3; Molecular Devices, San Jose, CA, United States) at 540-nm emission and 580-nm extinction (Maciel et al., 2020).

\section{Measurement of Mitochondrial Swelling}

The integrity of the mitochondrial membrane was assessed by osmotically induced volume changes of the mitochondria and spectrophotometric determination of the apparent absorption of the suspension at $540 \mathrm{~nm}$. A mitochondrial suspension $(200 \mathrm{mg} / \mathrm{ml})$ was added to the respiration medium in the absence of respiratory substrates, at $37^{\circ} \mathrm{C}$, and under constant stirring. Mitochondrial swelling was stimulated with $1 \mu \mathrm{l}$ of calcium chloride at $20 \mu \mathrm{mol} / \mathrm{l}$ to reach $100 \mathrm{nmol} / \mathrm{l}$ in $200 \mu \mathrm{l}$ of mitochondrial suspension. Swelling was expressed as percentage of the absorption of the solution containing mitochondria in the presence of cyclosporin $\mathrm{A}$ $10 \mu \mathrm{mol} / \mathrm{l}$ (mitochondrial swelling $=0 \%$ ) in relation to that absorbed after the addition of FCCP $1 \mu \mathrm{mol} / \mathrm{l}$ (mitochondrial swelling $=100 \%)$.

\section{Measurement of Mitochondrial Transmembrane Potential $(\Delta \Psi \mathrm{m})$}

For $\Delta \Psi \mathrm{m}$ determination, the probe tetramethylrhodamine methyl ester (TMRM, $400 \mathrm{nmol} / \mathrm{l}$ ) was added to the respiration solution containing $200 \mathrm{mg} / \mathrm{ml}$ of mitochondria and incubated for $1 \mathrm{~h}$ at $4^{\circ} \mathrm{C}$ before the experiment. $\Delta \Psi \mathrm{m}$ was estimated by the fluorescence emitted by TMRM under 580-nm excitation. $\Delta \Psi \mathrm{m}$ was expressed as the percentage of fluorescence emitted by TMRM-labeled mitochondria in the presence of cyclosporin
A (mitochondrial despolarization $=0 \%$ ), relative to that emitted after the addition of FCCP to fully depolarize the mitochondria ( mitochondrial despolarization $=100 \%)$.

\section{Electron Leakage and ATP/ROS Production Ratio}

Electron leakage is the loss of the electron from the electron transport chain to form superoxide $\left(\mathrm{O}_{2}-\right)$. However, other reactive oxygen species, such as hydroperoxyl radical $\left(\mathrm{HO}_{2}\right)$ and hydrogen peroxide $\left(\mathrm{H}_{2} \mathrm{O}_{2}\right)$, might occur spontaneously (e.g., $\mathrm{pH}$-dependent) or under the action of antioxidant enzymes (e.g., superoxide dismutase). The site of initial leakage is often considered to be a semiquinone radical $(\mathrm{QH})$ or reduced flavin (FMN and FAD) (A-B). To calculate the fraction of electrons that leaked out of the respiratory chain, the rate of $\mathrm{H}_{2} \mathrm{O}_{2}$ formation (see section $\mathrm{E}$ ) is divided by the rate of mitochondrial $\mathrm{O}_{2}$ consumption (see section $\mathrm{C}$ ). $\mathrm{H}_{2} \mathrm{O}_{2}$ production and oxygen consumption rates must be expressed using the same units and correspond to the same respiratory state $(\mathrm{C}-\mathrm{E})$. The ATP/ROS reason should be measured to determine the formation of ROS linked to $\mathrm{O}_{2}$ consumption. Thus, we were able to determine the electron leakage inherent to ROS production (Santiago et al., 2008; Murphy, 2009; Jastroch et al., 2010; Daussin et al., 2012).

\section{Statistical Analysis}

Three experimental groups were tested. The first one corresponded to isolated mitochondria from hearts with a protein load of $50 \mu \mathrm{g}$ in each experiment. The second group consisted of isolated mitochondria from lungs with a protein load of $50 \mu \mathrm{g}$ in each experiment. The third group contained mitochondria isolated from lungs with a protein load of $200 \mu \mathrm{g}$ in each experiment. For graphic and statistical analysis, the software GraphPad Prism 8.4.3 (San Diego, CA, United States) was used. The significance of observed differences in mitochondrial oxygen consumption and functions was evaluated by the parametric one-Way ANOVA test followed by Tukey's multiple comparisons test. In all cases, $p<0.05$ was considered to be significant. Experimental values are reported as mean \pm standard deviation.

\section{RESULTS}

The differences between the present protocol and previous protocols are shown in Table 1.

\section{Mitochondrial Respiration}

Figure 3A depicts that the mitochondrial oxygen consumption by complex I under state 1 was smaller in lung mitochondria$50 \mu \mathrm{g}\left(1.43 \pm 0.39 \mathrm{nmol} \mathrm{O} \mathrm{O}_{2} / \mathrm{min} / \mathrm{mg}\right.$ protein $)$ than in heart mitochondria $(2.68 \pm 0.46 \mathrm{nmol} \mathrm{O} / 2 / \mathrm{min} / \mathrm{mg}$ protein, $p=0.006)$ and in lung mitochondria-200 $\mu \mathrm{g}\left(2.52 \pm 0.45 \mathrm{nmol} \mathrm{O}_{2} / \mathrm{min} / \mathrm{mg}\right.$ protein, $p=0.01)$, which did not differ between them $(p=0.7)$.

As shown in Figure 3B, the mitochondrial oxygen consumption by Complex I under state 2 is smaller in lung mitochondria-50 $\mu \mathrm{g}(10.79 \pm 3.3 \mathrm{nmol} \mathrm{O} / 2 \mathrm{~min} / \mathrm{mg}$ protein $)$ than in heart mitochondria $(33.51 \pm 4.7 \mathrm{nmol} \mathrm{O} / \mathrm{min} / \mathrm{mg}$ protein, $p=0.001)$ and in lung mitochondria-200 $\mu \mathrm{g}(33.78 \pm 7 \mathrm{nmol}$ 
$\mathrm{O}_{2} / \mathrm{min} / \mathrm{mg}$ protein, $p=0.006$ ), which did not differ between them $(p=0.99)$.

The mitochondrial oxygen consumption by complex I under state 3 was smaller in lung mitochondria-50 $\mu \mathrm{g}$ $\left(26.75 \pm 8.2 \mathrm{nmol} \mathrm{O}_{2} / \mathrm{min} / \mathrm{mg}\right.$ protein) than in heart mitochondria $(73.83 \pm 8.38 \mathrm{nmol} \mathrm{O} / 2 / \mathrm{min} / \mathrm{mg}$ protein, $p=0.01)$ and in lung mitochondria- $200 \mu \mathrm{g}(61.67 \pm 9.1 \mathrm{nmol} \mathrm{O} 2 / \mathrm{min} / \mathrm{mg}$ protein, $p=0.0006$ ), which did not differ, $p=0.99$, as presented in Figure 3C.

The mitochondrial oxygen consumption by complex II under state 3 was smaller in lung mitochondria-50 $\mu \mathrm{g}(35.54 \pm 11 \mathrm{nmol}$ $\mathrm{O}_{2} / \mathrm{min} / \mathrm{mg}$ protein) than in heart mitochondria-50 $\mu \mathrm{g}$ $\left(100.5 \pm 12.4 \mathrm{nmol} \mathrm{O}_{2} / \mathrm{min} / \mathrm{mg}\right.$ protein, respectively, $\left.p=0.003\right)$, and in lung mitochondria-200 $\mu \mathrm{g}(69.32 \pm 11.3 \mathrm{nmol}$ $\mathrm{O}_{2} / \mathrm{min} / \mathrm{mg}$ protein, $\left.p=0.0053\right)$. However, the increase in oxygen consumption by lung mitochondria- $200 \mu \mathrm{g}$ did not reach the level of the heart mitochondria-50 $\mu \mathrm{g}(p=0.009)$, as shown in Figure 3D.

Figure 3E shows that the mitochondrial oxygen consumption by complex IV was smaller in lung mitochondria-50 $\mu \mathrm{g}$ $\left(273.3 \pm 59 \mathrm{nmol} \mathrm{O}_{2} / \mathrm{min} / \mathrm{mg}\right.$ protein) than in heart mitochondria-50 $\mu \mathrm{g}\left(419.5 \pm 43 \mathrm{nmol} \mathrm{O}_{2} / \mathrm{min} / \mathrm{mg}\right.$ protein, $p=0.003)$ and lung mitochondria-200 $\mu \mathrm{g}(392.1 \pm 72.4 \mathrm{nmol}$ $\mathrm{O}_{2} / \mathrm{min} / \mathrm{mg}$ protein, $p=0.047$ ), which did not differ between them $(p=0.19)$. The mitochondrial oxygen consumption by maximal oxygen uptake of uncoupled mitochondria was similar in heart mitochondria-50 $\mu \mathrm{g}$ and lung mitochondria-50 $\mu \mathrm{g}$ $\left(402.5 \pm 57.5\right.$ and $369.51 \pm 72.8 \mathrm{nmol} \mathrm{O}_{2} / \mathrm{min} / \mathrm{mg}$ protein, respectively, $p=0.7)$. Lung mitochondria- $200 \mu \mathrm{g}$ showed similar respiration to heart mitochondria-50 $\mu \mathrm{g}(393.45 \pm 86.12 \mathrm{nmol}$ $\mathrm{O}_{2} / \mathrm{min} / \mathrm{mg}$ protein, $p=0.17$ vs. heart mitochondria- $50 \mu \mathrm{g}$ ) and $p=0.5$ vs. lung mitochondria-50 $\mu \mathrm{g})$ (Figure 3E).

\section{Mitochondrial ROS Production}

Mitochondrial ROS production by lung mitochondria-50 $\mu \mathrm{g}$ $(21.87 \pm 9.6 \mathrm{nmol} /$ loaded protein) was lower than that by heart mitochondria-50 $\mu \mathrm{g}(66.08 \pm 12.5 \mathrm{nmol} /$ loaded protein, $p=0.003$ ) and lung mitochondria-200 $\mu \mathrm{g}$ $(63.64 \pm 12.3 \mathrm{nmol} /$ loaded $\mu \mathrm{g}$ protein, $p=0.0015)$, which was similar $(p=0.87)$, as displayed in Figure 4A.

\section{Mitochondrial Adenosine 5'-Triphosphate Production}

Figure $4 \mathrm{~B}$ shows that mitochondrial the ATP production by lung mitochondria-50 $\mu \mathrm{g}(22.92 \pm 9.12 \mu \mathrm{mol}$ ATP/loaded protein) was lower than that by heart mitochondria-50 $\mu \mathrm{g}$ $(91.62 \pm 5.9 \mu \mathrm{mol}$ ATP/loaded protein, $p=0.0001)$ and lung mitochondria-200 $\mu \mathrm{g}(83.51 \pm 9.49 \mu \mathrm{mol}$ ATP/loaded protein, $p=0.006)$, which was similar $(p=0.075)$.

\section{Mitochondrial Swelling}

The mitochondrial swelling of lung mitochondria-50 $\mu \mathrm{g}$ (68.5 $\pm 19.7 \%$ maximum $)$, heart mitochondria-50 $\mu \mathrm{g}(63.9 \pm 13.8 \%$ maximum), and lung mitochondria- $200 \mu \mathrm{g}(81.84 \pm 15.35 \%$ maximum) did not differ among them $(p=0.3)$, as depicted in Figure 4C. 
A

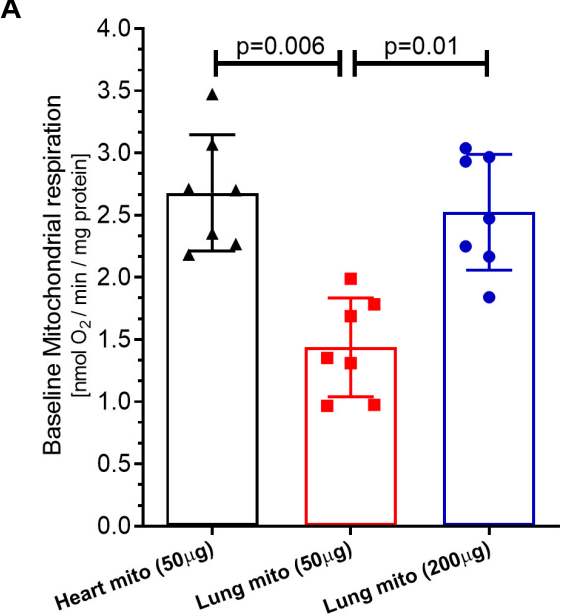

C



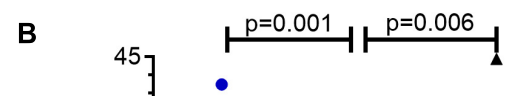

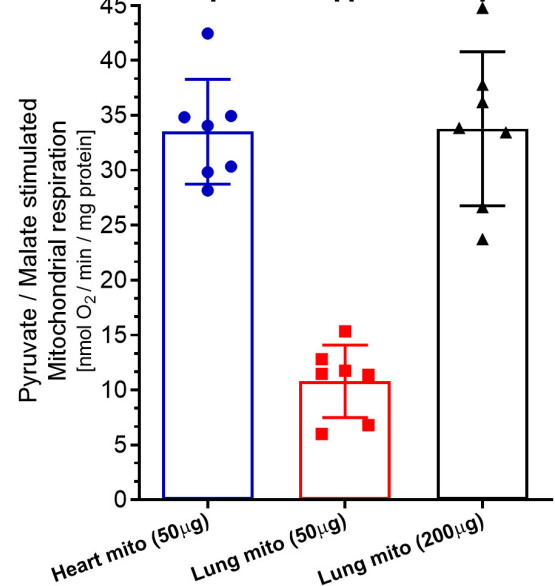

D



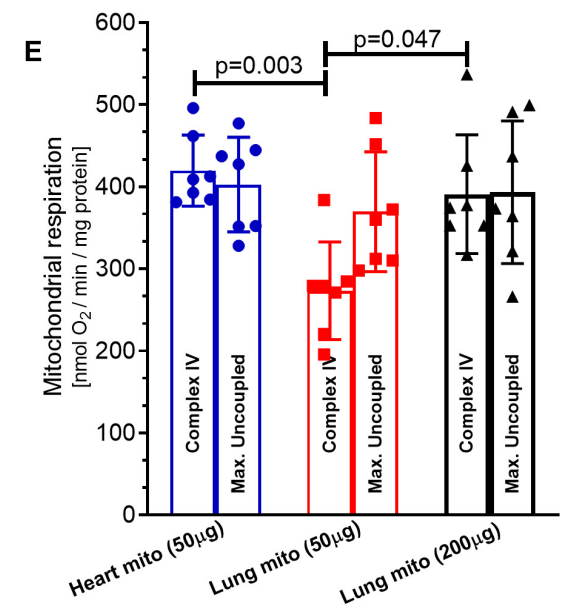

FIGURE 3 | Mitochondrial respiration. (A) Baseline respiration (state 1 complex 1), (B) pyruvate/malate stimulation (state 2 complex 1 ) respiration, (C) adenosine diphosphate (ADP) stimulation (state 3 complex 1) respiration. (D) Complex II respiration was stimulated with succinate and using the complex I inhibitor Rotenone. (E) Complex IV respiration stimulated with N,N,N,N-tetramethyl-p-phenylenediamine dihydrochloride (TMPD) and ascorbate and maximal uncoupled oxygen uptake induced by carbonyl cyanide 4-(trifluoromethoxy)phenylhydrazone (FCCP) of isolated mitochondria from mice heart and lung. Heart mito (50 $\mu \mathrm{g}$ ) represents the group of isolated mitochondria from hearts. Lung mito $(50 \mu \mathrm{g})$ indicates the group of isolated mitochondria from lungs with loading of $50 \mu \mathrm{g}$. Lung mito (200 $\mu \mathrm{g}$ ) signals the group of isolated mitochondria from lungs with loading of $200 \mu \mathrm{g}$. Each symbol represents one animal. The values are reported as mean \pm standard deviation. Horizontal square brackets indicate significantly different differences and the corresponding $p$-value. 


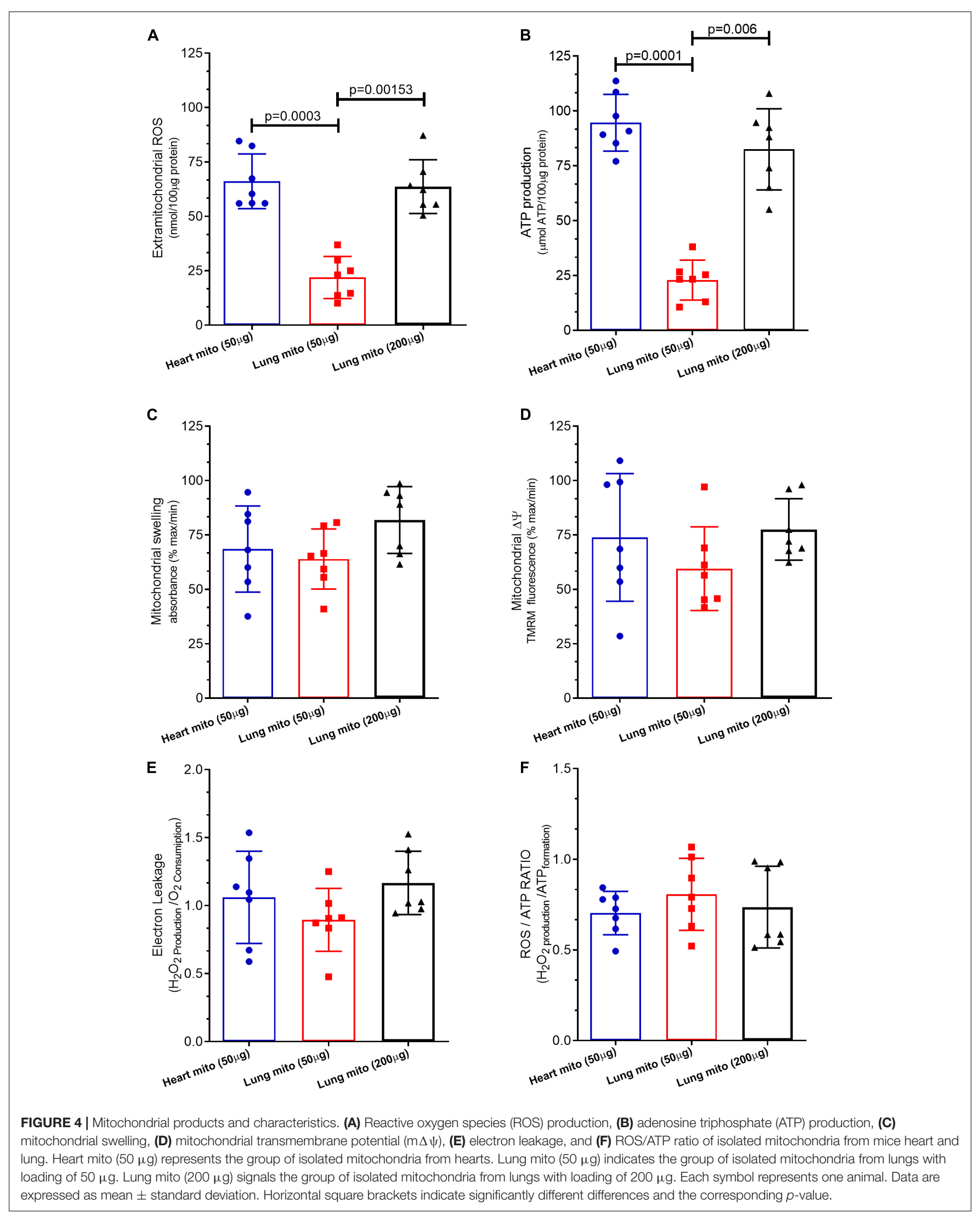




\section{Mitochondrial $\Delta \psi$}

The mitochondrial $\Delta \psi \mathrm{m}$ of lung mitochondria-50 $\mu \mathrm{g}$ (73.84 $\pm 29.3 \%$ maximum), heart mitochondria-50 $\mu \mathrm{g}$ (59.46 $\pm 19.2 \%$ maximum), and lung mitochondria-200 $\mu \mathrm{g}$ $(77.51 \pm 14.1 \%$ maximum) did not differ among them $(p=0.52)$ (Figure 4D).

\section{Mitochondrial Proton Leakage}

Figure $4 \mathrm{E}$ shows that the mitochondrial proton leakage by lung mitochondria-50 $\mu \mathrm{g}\left(1.04 \pm 0.39 \mathrm{H}_{2} \mathrm{O}_{2}\right.$ production $/ \mathrm{O}_{2}$ consumption), heart mitochondria-50 $\mu \mathrm{g}\left(0.84 \pm 0.31 \mathrm{H}_{2} \mathrm{O}_{2}\right.$ production $/ \mathrm{O}_{2}$ consumption), and lung mitochondria- $200 \mu \mathrm{g}$ $\left(0.97 \pm 0.22 \mathrm{H}_{2} \mathrm{O}_{2}\right.$ production/ $\mathrm{O}_{2}$ consumption) was similar $(p=0.48)$.

\section{Mitochondrial ATP/ROS Ratio}

The mitochondrial ATP/ROS ratio of lung mitochondria$50 \mu \mathrm{g}\left(1.26 \pm 0.19 \mathrm{H}_{2} \mathrm{O}_{2}\right.$ production/ATP formation), heart mitochondria-50 $\mu \mathrm{g}\left(1.07 \pm 0.42 \quad \mathrm{H}_{2} \mathrm{O}_{2}\right.$ production/ATP formation), and lung mitochondria-200 $\mu \mathrm{g}\left(1.39 \pm 0.35 \mathrm{H}_{2} \mathrm{O}_{2}\right.$ production/ATP formation) did not differ $(p=0.54)$, as depicted in Figure 4F.

\section{DISCUSSION}

We used herein a new protocol with specific and detailed steps aiming to improve mitochondrial isolation from lung tissue. It was abridgedly published (Caldeira et al., 2021) but not tested against a well-documented and broadly used one (Gedik et al., 2017). This new protocol improves the acquisition of a robust and preserved sample of isolated mitochondria, allowing a range of analyses with the same sample, increasing mitochondria viability and experimental reproducibility. Here, we describe step-by-step the instructions for lung mitochondria isolation and warn for critical steps (steps of the procedure in which the researcher must be extremely careful, or attentive, with the procedure for the perfect execution of the isolation). Before our improved method, there was no consensus concerning protocols for mitochondrial isolation from the lung tissue (Zhang et al., 2018). The isolation of mitochondria from lung tissue is extremely difficult, because of the elevated fatty acid content and low load of mitochondria in pulmonary cells (Spear and Lumeng, 1978). Therefore, the isolation buffer most contain a high amount of fat-free BSA to be bound to free fatty acids. Noteworthy is that the amount of fat-free BSA used to isolate mitochondria from cardiomyocytes (Maciel et al., 2020) is half of that used to isolate mitochondria from the lung.

The integrity of the membrane in the lung-isolated mitochondria is of paramount importance (Zhang et al,, 2018). Consequently, we detailed each step of our protocol very carefully. Because of lung intrinsic characteristic as an air-filled organ, there are difficulties in stages that aim to mince the tissue and remove the residual blood (Spear and Lumeng, 1978). The removal of blood (including hemoglobin) from tissue is mandatory to avoid oxygen sequestration during $\mathrm{O}_{2}$ consumption assay. This singular lung characteristic undermines the isolation of mitochondria, resulting in low success rate and small amount of mitochondria available for putatively several functional tests (Spear and Lumeng, 1978). These issues pertaining to an air-filled highly perfused organ were overcome by our improved method. Thus, we showed that it is possible to appropriately mince the lung and remove its blood content without losing large amounts of sample.

We compared mitochondrial functional characteristics using three experimental groups. The first one (control group) comprised mitochondria isolated from the heart carrying $50 \mu \mathrm{g}$ of protein per experiment. Heart mitochondria are isolated by means of a well-established broadly used protocol (Schulz et al., 2015; Gedik et al., 2017; Maciel et al., 2020, 2021). The second experimental group contained isolated lung mitochondria carrying $50 \mu \mathrm{g}$ of protein per experiment, the same loading as isolated heart mitochondria. The third experimental group consisted of isolated lung mitochondria at a concentration of $200 \mu \mathrm{g}$ of protein per experiment. Mitochondrial respiration was measured with a Clark-type electrode at $37^{\circ} \mathrm{C}$ during magnetic stirring and consistently demonstrated that the concentration of lung-isolated mitochondria can affect the results. An identical concentration of lung- and cardiomyocyte-isolated mitochondria $(50 \mu \mathrm{g})$ yielded smaller oxygen consumption by lung mitochondria at baseline respiration (Figures 2A, 3A), following pyruvate/malate (Figures 2A,B), ADP (Figures 2A, 3C), and TMPD/ascorbate (Figures 2A, 3D) titration. Taken together, these data strongly indicate that the loading of the lung mitochondria is not adequate using the $50 \mu \mathrm{g}$ protein concentration. Protein dosage is an indirect measure of the concentration of mitochondria; therefore, a loading control that assesses functionality is necessary (Maciel et al., 2020). For such a purpose, the activation of mitochondrial complex IV is commonly employed as a loading control (Schulz et al., 2015; Gedik et al., 2017; Maciel et al., 2020, 2021), and we observed that the oxygen consumption in complex IV was less in isolated lung mitochondria loaded with $50 \mu \mathrm{g}$ of protein than in the group of isolated heart mitochondria. Interestingly, heart isolated mitochondria presented similar values to those from lung isolated mitochondria loaded with $200 \mu \mathrm{g}$ of protein (Figures 2B, 3). These data could suggest that lung tissue yields fewer mitochondria, and that greater loading is required to generate data comparable to those from heart tissue mitochondria. However, we cannot exclude the possibility that cardiac mitochondrion may have higher metabolism than lung mitochondria (Zhang et al., 2018; Spear and Lumeng; 1978). On the other hand, our FCCP-induced uncoupled respiration did not differ between all groups, suggesting that the mitochondria groups appear to have similar viability and behavior (Schulz et al., 2015; Gedik et al., 2017; Maciel et al., 2020, 2021). Indeed, $200 \mu \mathrm{g}$ of protein per experiment is an acceptable amount, and our samples of isolated mitochondria had enough material to grant the completion of several experiments. Other techniques to analyze mitochondrial function, such as ATP production (Figure 4A) and ROS formation (Figure 4B), display the same trend. On the other hand, mitochondrial swelling (Figure 4C), mitochondrial transmembrane potential (Figure 4D), electron leakage (Figure 4E), and ROS/ATP ratio (Figure 4F) did not show a significant difference among the three groups, perhaps 
because mitochondrial swelling is analyzed by light scattering in the assay (Chapa-Dubocq et al., 2018). Mitochondrial transmembrane potential is analyzed by the stimulation of a fluorophore (Creed and McKenzie, 2019); and electron leakage and ROS/ATP ratio are calculated from existing data that were not challenged by experimental maneuvers (Santiago et al., 2008; Murphy, 2009; Jastroch et al., 2010; Daussin et al., 2012).

\section{Limitations}

The lung is an extremely complex organ with regard to the heterogeneity of cells. Our method does not contemplate analyzing all 40 subtypes of cells found in the lung. However, this heterogeneity is an intrinsic part of the lung, and all methods of mitochondria isolation, for most diverse tissues, contemplate entire organ isolation, because different cells form a syncytium for the organ to work, e.g., the heart (Gedik et al., 2017), kidney (Schulz et al., 2015), liver (Goudarzi et al., 2018), adipose tissue (Matta et al., 2021), and brain (Marques Neto et al., 2020).

\section{CONCLUSION}

Based on the method briefly described by Caldeira et al. (2021), we developed an optimized and successful technique for the isolation of mitochondria from lung tissue. We extensively described the technical difficulties concerning tissue quantity, tissue characteristics, tissue adjunct components, time of isolation, and the use of proteinases. Additionally, we described the experimental determination of several mitochondrial functional characteristics, providing information that might improve the reproducibility and analysis of lung tissue mitochondria. Ultimately, the method yielded a robust, maintained, and viable sample of pulmonary mitochondria.

\section{REFERENCES}

Caldeira, D., Mesquita, F. M., Pinheiro, F. G., Oliveira, D. F., Oliveira, L., Nascimento, J., et al. (2021). Acute exposure to C60 fullerene damages pulmonary mitochondrial function and mechanics. Nanotoxicology $\quad 15, \quad 352-365$. doi: $10.1080 / 17435390.2020 .186$ 3498

Chapa-Dubocq, X., Makarov, V., and Javadov, S. (2018). Simple kinetic model of mitochondrial swelling in cardiac cells. J. Cell. Physiol. 233, 5310-5321. doi: 10.1002/jcp. 26335

Creed, S., and McKenzie, M. (2019). Measurement of mitochondrial membrane potential with the fluorescent dye tetramethylrhodamine methyl ester (TMRM). Methods Mol. Biol. 1928, 69-76. doi: 10.1007/978-1-4939-9027-6_5

Daussin, F. N., Rasseneur, L., Bouitbir, J., Charles, A. L., Dufour, S. P., Geny, B., et al. (2012). Different timing of changes in mitochondrial functions following endurance training. Med. Sci. Sports Exerc. 44, 217-224. doi: 10.1249/mss. 0b013e31822b0bd4

Gedik, N., Maciel, L., Schulte, C., Skyschally, A., Heusch, G., and Kleinbongard, P. (2017). Cardiomyocyte mitochondria as targets of humoral factors released by remote ischemic preconditioning. Arch. Med. Sci. 13, 448-458. doi: 10.5114/ aoms.2016.61789

Goudarzi, M., Kalantari, H., and Rezaei, M. (2018). Glyoxal toxicity in isolated rat liver mitochondria. Hum. Exp. Toxicol. 37, 532-539. doi: 10.1177/ 0960327117715900

\section{DATA AVAILABILITY STATEMENT}

The raw data supporting the conclusions of this article will be made available by the authors, without undue reservation.

\section{ETHICS STATEMENT}

The animal study was reviewed and approved by the UFRJlocal Institutional Animal Care and Use Committee (015/17). Written informed consent was obtained from the owners for the participation of their animals in this study.

\section{AUTHOR CONTRIBUTIONS}

LM, WZ, and JN: conception and design, data acquisition, analysis and interpretation of data, drafting or revising the article, and contribution with reagents. DC, DO, and JC-d-A: data acquisition, and analysis and interpretation of data. LM was the principal investigator. All the authors discussed the results, commented on the manuscript, and approved the final version of the manuscript.

\section{FUNDING}

This study was supported by the Brazilian Council for Scientific and Technological Development (CNPq, grants 302702/20172) and the Carlos Chagas Filho Rio de Janeiro State Research Supporting Foundation (FAPERJ, grants E-26/202.785/2017 and E26/010.002585/2019). The funding sources had no involvement in study design; collection, analysis, and interpretation of data; writing of the report; and decision to submit the article for publication.

Jastroch, M., Divakaruni, A. S., Mookerjee, S., Treberg, J. R., and Brand, M. D. (2010). Mitochondrial proton and electron leaks. Essays Biochem. 47, 53-67. doi: 10.1042/bse0470053

Kuznetsov, A. V., Veksler, V., Gellerich, F. N., Saks, V., Margreiter, R., and Kunz, W. S. (2008). Analysis of mitochondrial function in situ in permeabilized muscle fibers, tissues and cells. Nat. Protoc. 3, 965-976. doi: 10.1038/nprot. 2008.61

Lanza, I. R., and Sreekumaran Nair, K. (2009). Functional assessment of isolated mitochondria in vitro. Methods Enzymol. 457, 349-372. doi: 10.1016/s00766879(09)05020-4

Maciel, L., de Oliveira, D. F., Mesquita, F., Souza, H., Oliveira, L., Christie, M., et al. (2021). New cardiomyokine reduces myocardial ischemia/reperfusion injury by PI3K-AKT pathway via a putative KDELreceptor binding. J. Am. Heart Assoc. 10:e019685. doi: 10.1161/JAHA.120.01 9685

Maciel, L., de Oliveira, D. F., Monnerat, G., Campos de Carvalho, A. C., and Nascimento, J. (2020). Exogenous $10 \mathrm{kDa}$-heat shock protein preserves mitochondrial function after hypoxia/reoxygenation. Front. Pharmacol. 11:545. doi: 10.3389/fphar.2020.00545

Marques Neto, S. R., Castiglione, R. C., da Silva, T., Paes, L., Pontes, A., Oliveira, D. F., et al. (2020). Effects of high intensity interval training on neurocardiovascular dynamic changes and mitochondrial dysfunction induced by high-fat diet in rats. PLoS One 15:e240060. doi: 10.1371/journal.pone.024 0060 
Matta, L., Fonseca, T. S., Faria, C. C., Lima-Junior, N. C., De Oliveira, D. F., Maciel, L., et al. (2021). The effect of acute aerobic exercise on redox homeostasis and mitochondrial function of rat white adipose tissue. Oxid. Med. Cell. Longev. 2021:4593496. doi: 10.1155/2021/459 3496

Meyer, J. N., Leuthner, T. C., and Luz, A. L. (2017). Mitochondrial fusion, fission, and mitochondrial toxicity. Toxicology 391, 42-53. doi: 10.1016/j.tox.2017.07. 019

Murphy, M. P. (2009). How mitochondria produce reactive oxygen species. Biochem. J. 417, 1-13. doi: 10.1042/bj20081386

Murphy, M. P., and Hartley, R. C. (2018). Mitochondria as a therapeutic target for common pathologies. Nat. Rev. Drug Discov. 17, 865-886.

Perry, C. G., Kane, D. A., Lanza, I. R., and Neufer, P. D. (2013). Methods for assessing mitochondrial function in diabetes. Diabetes Metab. Res. Rev. 62, 1041-1053. doi: 10.2337/db12-1219

Picard, M., Taivassalo, T., Gouspillou, G., and Hepple, R. T. (2011). Mitochondria: isolation, structure and function. J. Physiol. 589, 4413-4421. doi: 10.1113/ jphysiol.2011.212712

Santiago, A. P., Chaves, E. A., Oliveira, M. F., and Galina, A. (2008). Reactive oxygen species generation is modulated by mitochondrial kinases: correlation with mitochondrial antioxidant peroxidases in rat tissues. Biochimie 90, 15661577. doi: 10.1016/j.biochi.2008.06.013

Schulz, S., Lichtmannegger, J., Schmitt, S., Leitzinger, C., Eberhagen, C., Einer, C., et al. (2015). A protocol for the parallel isolation of intact mitochondria from rat liver, kidney, heart, and brain. Methods Mol. Biol. 1295, 75-86. doi: 10.1007/978-1-4939-2550-6_7
Spear, R. K., and Lumeng, L. (1978). A method for isolating lung mitochondria from rabbits, rats, and mice with improved respiratory characteristics. Anal. Biochem. 90, 211-219. doi: 10.1016/0003-2697(78)90025-8

Weissig, V. (2005). Targeted drug delivery to mammalian mitochondria in living cells. Expert Opin. Drug Deliv. 2, 89-102. doi: 10.1517/17425247.2.1.89

Zhang, X., Dash, R. K., Jacobs, E. R., Camara, A. K. S., Clough, A. V., and Audi, S. H. (2018). Integrated computational model of the bioenergetics of isolated lung mitochondria. PLoS One 13:e0197921. doi: 10.1371/journal.pone.0197921

Conflict of Interest: The authors declare that the research was conducted in the absence of any commercial or financial relationships that could be construed as a potential conflict of interest.

Publisher's Note: All claims expressed in this article are solely those of the authors and do not necessarily represent those of their affiliated organizations, or those of the publisher, the editors and the reviewers. Any product that may be evaluated in this article, or claim that may be made by its manufacturer, is not guaranteed or endorsed by the publisher.

Copyright (C) 2021 Caldeira, Oliveira, Cavalcanti-de-Albuquerque, Nascimento, Zin and Maciel. This is an open-access article distributed under the terms of the Creative Commons Attribution License (CC BY). The use, distribution or reproduction in other forums is permitted, provided the original author(s) and the copyright owner(s) are credited and that the original publication in this journal is cited, in accordance with accepted academic practice. No use, distribution or reproduction is permitted which does not comply with these terms. 